\title{
Analisis Perkembangan Kognitif Anak Usia Dasar dan Implikasinya dalam Kegiatan Belajar Mengajar
}

\author{
DianAndesta Bujuri \\ Fakultas Ilmu Tarbiyah dan Keguruan \\ Universitas Islam Negeri Sunan Kalijaga Yogyakarta \\ Jalan Laksda Adisucipto, Caturtunggal, Depok, Kabupaten Sleman, \\ Daerah Istimewa Yogyakarta 55281 \\ dianandesta819@gmail.com
}

\begin{abstract}
The human as human being should experience the development every time, including on the basic age of child (7-13 years old). One of important aspects of human development is cognitive aspect. Cognitive development is an comprehensive development relating with thinking ability, such as the ability of thingking, reasoning, expressing idea, imagination and creativity. According to Piaget's theory, the cognitive development of basic age child consists of two phases: the first is concrete operational phase (7-11 years old) that is a phase where the child has been able to function his/her mind to think logical, rational and objective, but it is just limited on the object concrete. The second is formal operational phase (11-12 more years old) that is a phase where the child has used his/her mind to think a matter which will be or ought to be happening (hyphotheses) and a abstract matter. In spite of the same phase, cognitive development of child has difference in every age level that it is very significant to be known especially in education scope in teaching and learning process. Referred to new version of Talksonomi Bloom Theory, the child who is 7 years old has been at C1, C2 and C3 level but it is still limited, age 8 years is C2 and C3 level; age 9 years is C3 level which is high level; age 10 years is C3, C4 and C5 level which is limited, age 11 years is C4, C5 and C5 level; and 12 years more is C6 level which is better. The significance of comprehension about the cognitive ability level of child becomes reference to choose material lesson, to determine strategy, model and learning method. The purpose is to able to create effective learning and to be able to comprehend the material maximally which it is hopefully compatible with the belonging of child's cognitive ability.
\end{abstract}

Keyword: cognitive development, basic age child, teaching and learning

\begin{abstract}
Abstrak
Manusia sebagai makhluk hidup mesti mengalami perkembangan disetiap waktunya, tak terkecuali pada anak usia dasar (7-13 tahun). Salah satu aspek penting dari perkembangan adalah aspek kogntif. Perkembangan kognitif merupakan suatu perkembangan yang sangat komprehensif yaitu berkaitan dengan kemampuan berfikir, seperti kemampuan mengingat, bernalar, beride, berimajinasi dan kreatifitas. Menurut teori kognitif Piaget, perkembangan kognitif anak usia dasar berada pada dua fase yaitu pertama fase operasional konkret (7-11 tahun) adalah fase dimana anak sudah dapat memfungsikan akalnya untuk berfikir logis, rasional dan objektif, tetapi terhadap objek yang bersifat konkret. Kedua fase operasional formal (11-12 tahun ke atas) adalah fase dimana anak sudah dapat memikirkan sesuatu yang akan atau mungkin terjadi (hipotesis) dan sesuatu bersifat abstrak. Kendati berada pada fase yang sama, perkembangan
\end{abstract}


kognitif anak memiliki perbedaan di setiap tingkatan usianya yang sangat penting dipahami khususnya dalam lingkup pendidikan yaitu pada kegiatan belajar megajar (KBM). Mengacu pada teori Talksonomi Bloom versi baru, anak usia 7 tahun berada pada jenjang C1, C2 dan C3 tetapi masih terbatas; usia 8 tahun berada pada jenjang C2 dan C3; usia 9 tahun berada pada jenjang C3 level tinggi; anak usia 10 tahun berada pada jenjang C3, C4 dan C5 tetapi masih terbatas; usia 11 tahun berada pada jenjang C4, C5 dan C6; dan usia 12 ke atas tahun ke atas berada pada jenjang C6 yang lebih baik. Pentingnya pemahaman terhadap jenjang kemampuan kognitif anak tersebut menjadi pedoman dalam memilih materi, menentukan strategi, model dan metode pembelajaran. Tujuannya, agar terwujudnya pembelajaran yang efektif dan anak dapat memahami materi secara maskimal, sesuai dengan kemampuan kognitif yang dimiliki.

\section{Kata Kunci: perkembangan kognitif, anak usia dasar, KBM}

\section{PENDAHULUAN}

Manusia merupakan makhluk hidup yang mengalami pertumbuhan dan perkembangan disetiap waktunya, mulai dari masa pranatal hingga diakhir hayatnya. Pertumbuhan dan perkembangan manusia mencakup berbagai aspek yang dalam hal ini penulis membaginya menjadi dua yaitu aspek fisik dan non- fisik. Perkembangan pada aspek fisik manusia terdiri dari perkembangan tinggi badan, berat badan, motorik (otot dan syaraf) dan perkembangan otak, sedangkan perkembangan non-fisik manusia terdiri dari perkembangan kognitif, sosio- emosional, dan perkembangan bahasa. Perkembangan fisik dan non-fisik manusia memiliki perbedaan disetiap individunya. Pekembangan salah satu individu bisa saja lebih cepat dan lebih baik dari pada perkembangan individu lainnya. Perbedaan-perbedaan tersebut terjadi karena adanya faktor usia, faktor genetika, faktor makanan dan faktor lingkungan.

Pengetahuan tentang perkembangan manusia sangat penting diketahui dan dipahami sebagai pedoman dalam memahami kebutuhan dan karakter seseorang, tak terkecuali anak usia dasar. Anak usia dasar adalah anak yang berada dalam bentang usia 7-12 tahun ke atas atau dalam sistem pendidikan dapat disebut anak yang berada pada usia sekolah dasar. Memahami perkembangan anak usia dasar menjadi suatu keharusan bagi orang tua, guru dan orang yang lebih dewasa. seperti yang dikemukakan Hurlock (1978) bahwa "orang yang paling penting bagi anak adalah orang tua, guru, dan teman sebaya (peer group). Melalui merekalah anak mengenal sesuatu positif dan negatif'. Baik atau buruknya perkembangan anak sangat bergantung terhadap pemenuhan kebutuhan yang ia peroleh dari orang lain, baik dari orang tua, anggota keluarga, guru dan individu lainnya.

Mengingat, anak usia dasar belum memiliki kematangan dalam berfikir, anak memiliki keterbatasan dalam memilah dan memilih sesuatu yang positif atau negatif dan mana yang berdampak baik atau buruk.

Salah satu aspek yang sangat penting untuk diketahui dan dipahami dari perkembangan anak usia dasar adalah aspek kogntif. Perkembangan kognitif merupakan suatu perkembangan yang sangat komprehensif yaitu berkaitan dengan kemampuan berfikir, seperti kemampuan bernalar, mengingat, menghafal, memecahkan masalah-masalah nyata, beride dan kreatifitas. Perkembangan kognitif memberikan pengaruh terhadap perkembangan mental dan emosional anak serta kemampuan berbahasa. Sikap dan tindakan anak juga berkaitan dengan kemampuan berfikir anak. Sehingga, perkembangan kognitif dapat dikatakan sebagai kunci dari pada perkembangan-perkembangan yang bersifat non-fisik.

${ }^{1}$ Rakhmawati I., Peran Keluarga dalam Pengasuhan Anak, (Jurnal Bimbingan dan Konseling Islam, Vol. 6, No. 1, 2015), hlm. 3. 
Perkembangan kogitif anak usia dasar tentu tidak bisa disamakan dengan kemampuan kognitif anak remaja dan orang dewasa. Pada umumnya, kemampuan kognitif anak usia dasar masih terbatas dalam hal-hal yang bersifat konkret dan nyata, misalnya anak usia 6 atau 7 tahun dapat memahami gelas bisa pecah apabila dibenturkan dengan lantai, anak belum bisa menjawab penyebab pecahnya gelas tersebut secara ilmiah. Anak usia dasar memiliki keterbatasan berfikir terhadap hal yang bersifat abstrak, misalnya ketika anak usia 7-9 diberi pertanyaan tentang mengapa bumi mengelilingi matahari. Anak akan mengalami kesulitan bahkan merasa kebingungan untuk menjawab pertanyaan yang demikian secara ilmiah dan ketika dipaksa, justru anak akan merasa setres, karena kemampuan kognitifnya belum sampai pada tahap berfikir yang rumit.

Pada proses penyelenggaraan pendidikan Sekolah Dasar (SD) atau Madarasah Ibtidaiyah (MI), pemahaman tentang perkembangan kognitif anak usia dasar sangat penting untuk menjadi acuan dalam rangka mendidik dan mengajar. Kegiatan belajar mengajar (KBM) akan maksimal apabila materi ajar yang disampaikan dapat dipahami oleh anak. Hal tersebut dapat terjadi ketika tingkat kesukaran materi sesuai dengan taraf kemampuan berfikir anak. Faktanya, hasil dari suatu penelitian membuktikan bahwa terdapat ketidaksesuiaian antara materi yang terdapat di buku siswa (K13) dengan taraf kemampuan berfikir anak di SD/MI, sehingga tidak jarang di temukan para guru melakukan pengembangan bahan ajar secara personal dengan menyesuaikan kemampuan kognitif siswa. ${ }^{2}$ Apabila dalam KBM, materi yang disampaikan terlalu tinggi maka konsekuensi logisnya, tujuan pembelajaran tidak akan tercapai secara maskimal. Akibatnya, KBM hanya akan menjadi kegiatan yang sia-sia, anak tidak mendapatkan ilmu sesuai yang diharapkan bahkan tidak jarang mengalami setres.

${ }^{2}$ Hapsari, Penerapan Model Pembelajaran Kontruktivisme Untuk Meningkatkan Hasil Belajar IPA, (Jurnal Pendidikan Penabur No. 16, Tahun Ke-10, 2011), hlm. 34-45.
Selain dari pada materi ajar, pemahaman tentang perkembangan kognitif anak juga menjadi pedoman dalam menentukan strategi, model, metode dan tekik evaluasi dalam pembelajaran. Anak akan mudah paham apabila materi yang disampaikan oleh guru menggunakan metode yang sesuai dengan kemampuan berfkir anak. Misalnya, ketika belajar tentang Ilmu Pengetahuan Alam, guru tidak cukup dengan metode ceramah saja, guru mesti menggunakan metode eksperimen (praktek) atau memberikan contoh langsung terkait objek yang dipelajari (modelling), sebab kemampuan berfikir anak usia dasar (711 tahun) berada pada level berfikir konkret (nyata) bukan bersifat khayalan atau sesuatu yang abstrak. Dengan demikian, pemahaman tentang perkembangan kognitif anak usia dasar bukan suatu pemahaman yang dapat dianggap remeh, melainkan pemahaman yang sangat penting terhadap keberhasilan suatu proses KBM khususnya pencapaian pada kompetensi kognitif anak.

Berdasarkan uraian diatas, penulis melakukan suatu analisis yang subtantif dan komprehensif terkait dengan perkembangan kognitif anak usia dasar dan implikasinya dalam kegiatan belajar mengajar di SD/MI. Tujuan dari pada penelitian ini adalah untuk mengetahui taraf perkembangan kognitif anak usia dasar yang dimulai dari usia 7-12 tahun ke atas dan implikasinya terhadap kegiatan belajar mengajar yang mencakup aspek materi ajar, strategi, model dan metode pembelajaran. Harapannya, hasil penelitian ini dapat menambah khazanah keilmuan bagi khalayak umum dan menjadi referensi para guru dalam menjalankan amanahnya sebagai penagajar sekaligus pendidik dalam proses KBM.

\section{METODE PENELITIAN}

Metode penelitian yang digunakan dalam penelitian ini yaitu metode peneletian kualitatif. Metode penelitian kualitatif adalah metode penelitian yang digunakan untuk meneliti pada kondisi obyek alamiah, dimana peneliti 
adalah sebagai intrumen kunci. ${ }^{3}$ Berdasarkan objek kajian, penelitian ini termasuk penelitian yang bersifat litere atau kepustakaan (library research). library research adalah suatu peneltian yang dilakukan dengan cara mengumpulkan data, informasi dan berbagai macam data-data lainnya yang terdapat dalam kepustakaan. ${ }^{4}$ Sumber data yang digunakan dalam penelitian ini yaitu buku, jurnal, paper, artikel, dan karya ilmiah lainnya yang relevan dengan objek kajian pada penelitian ini. Pokok bahasan dalam penelitian ini yaitu teori-teori yang berkaitan dengan perkembangan kognitif anak usia dasar dan implikasinya dalam kegiatan belajar mengajar. Teknik pengumpulan data pada penelitian ini adalah dokumentasi. Selanjutnya, untuk mengolah dan menganalisis data, penulis menggunakan metode content analysis yaitu sebuah analisis terhadap kandungan isi yang berfokus pada interpretasi dari teori-teori kognitif anak usia dasar.

\section{HASIL DAN PEMBAHASAN}

Perkembangan kognitif berkaitan dengan perkembangan otak. Perkembangan otak yaitu perkembangan yang menyangkut ukuran (volume) dan fungsi otak. Kecepatan perkembangan otak berpengaruh terhadap perkembangan kognitif manusia. Pada usia 10 tahun berat otak sudah mencapai $95 \%$ dari otak orang dewasa, berbeda ketika bayi baru dilahirkan yang beratnya hanya $25 \%$ otak orang dewasa. ${ }^{5}$ Perkembangan otak akan mempengaruhi fungsi otak untuk berfikir, seperti mengetahui, memahami, menganalisis, mensintesis, beride, bernalar, berkreatifitas dan bertindak. Perkembangan otak terbagi menjadi dua bagian, yaitu otak kiri dan otak kanan. Perkembangan otak kiri meliputi kemampuan berfikir rasional, ilmiah, logis, analitis, dan

${ }^{3}$ Sugiyono, Memahami Penelitian Kualitatif, Cet. Ke-12, (Bandung : Alfabeta, 2016), hlm. 1.

${ }^{4}$ Subagyo, J., Metode Penelitian dan Praktek, (Jakarta : Rhineka Cipta, 1991), hlm. 109.

${ }^{5}$ Atien Nur chamidah, Deteksi Gangguan Pertumbuhan dan Perkembangan Anak, (Jurnal Pendidikan Khusus, Vol. 5 No. 2, 2009). berkaitan dengan kemampuan belajar membaca, berhitung dan bahasa. Perkembangan otak kanan meliputi kemampuan berfikir holistik, non-linier, non-verbal, intuitif, imajinatif dan kreatifitas.

Pada fase anak usia dasar, perkembangan kognitif anak memiliki tingkatan yang berbedabeda dimulai dari usia 7-12 tahun ke atas. Pada fase ini, perkembangan kognitif anak berada dalam dua fase yaitu pertama fase operasional konkret adalah fase ketika usia anak antara 7 sampai 11 tahun dan kedua fase operasional formal adalah fase ketika usia anak antara 11 sampai 12 tahun ke atas. Perkembangan kognitif setiap individu berbeda-beda, ada yang cepat dan ada juga yang lambat. Perbedaan tersebut dapat terjadi karena dipengaruhi berbagai faktor, diantaranya yaitu asupan gizi. Sebuah penelitian menunjukan bahwa anak kekurangan gizi (malnutrisi) memiliki IQ dengan rata-rata nilai 22,6 poin lebih rendah dibandingkan anak berstatus gizi baik. ${ }^{6}$ Selain dari faktor gizi, perkembangan kognitif juga dipengaruhi oleh faktor genetika, pendidikan dan lingkungan.

Perkembangan kognitif merupakan salah satu aspek terpenting untuk menjadi pedoman dalam proses pendidikan. Ranah kognitif adalah ranah yang berkaitan dengan tujuan belajar yang berorientasi pada kemampuan berpikir yang dalam pendidikan dikenal dengan istilah Talksonomi Bloom ranah kognitif. Terdapat 6 level dalam Talksonomi Bloom ranah kognitif yaitu mengingat (remember), memahami (understand), menerapkan (apply), menganalisis (analyze), menilai/mengevaluasi (evaluate), dan menciptakan (create). ${ }^{7}$ Keenam level ini merupakan hasil revisi yang dilakukan oleh Anderson dan Kratwohl dari versi sebelumnya

${ }^{6}$ Fithia Dyah Puspitasari, Toto Sudargo \& Indria Laksmi Gamayanti, Hubungan Antara Status Gizi dan Faktor Sosio Demografi dengan Kemampuan Kognitif Anak Sekolah Dasar Di Daerah Endemis Gaki, (Jurnal Gizi Indon, 34 (1) : 52-60, 2011).

${ }^{7}$ Imam Gunawan \& Anggarini Retno Palupi, Taksonomi Bloom - Revisi Ranah Kognitif : Kerangka Landasan Untuk Pembelajaran pengajaran, dan penilaian, (Journal Premiere Educandum : Pendidikan Dasar dan Pembelajaran, Vol. 2, No. 2, 2012). 
yaitu pengetahuan, pemahaman, penerapan, analisis, sintesis, evaluasi.

Beikut ini dideskripsikan mengenai kedua fase perkembangan kognitif anak dan implikasinya terhadap kegiatan belajar mengajar.

\section{Perkembangan kognitif anak usia tujuh sampai sebelas tahun dan implikasinya dalam kegiatan belajar mengajar}

Usia 7-11 tahun merupakan usia ketika anak sudah memasuki masa sekolah. Sebagaimana menurut teori kognitif Piaget, pemikiran anakanak usia sekolah dasar disebut pemikiran operasional konkret (concrete operational). ${ }^{8}$ Makna operasional konkret yang dimaksud oleh Piaget yaitu kondisi dimana anak-anak sudah dapat memfungsikan akalnya untuk berfikir logis terhadap sesuatu yang bersifat konkret atau nyata. Pada tahapan ini, pemikiran logis menggantikan pemikiran intuitif(naluri) dengan syarat pemikiran tersebut dapat diaplikasikan menjadi contoh-contoh yang konkret atau spesifik. ${ }^{9}$ Akan tetapi, kekurangan dari pada fase ini adalah ketika anak dihadapkan dengan pemasalahan yang bersifat abstrak (secara verbal) tanpa adanya objek nyata, maka ia akan mengalami kesulitan bahkan tidak mampu untuk menyelesaikannya dengan baik.

Penalaran anak masih terbatas, kendati dapat menalar secara logis dan memahami hubungan-hubungan kausal, mereka belum dapat melakukan penalaran hipotesis atau abstrak. ${ }^{10}$ Anak hanya dapat memecahkan suatu masalah ketika objek dari masalah tersebut bersifat empirik (nyata) atau ditangkap oleh paca indra mereka, bukan yang bersifat khayal. Misalnya, pada anak kelas satu, ketika diberi

${ }^{8}$ Desmita, Psikologi Perkembangan, Cet. Ke-9, (Bandung : PT Remaja Rosdakarya, 2015), hlm. 156.

${ }^{9}$ John W. Santrock, Perkembangan Anak, terj. Mila Rachmawati dan Anna Kuswanti, (Jakarta : Penerbit Erlangga, 2007), hlm. 255.

${ }^{10}$ Penney Upton, Psikologi Perkembangan, terj. Noermalasari Fajar Widuri, (Jakarta : Penerbit Erlangga, 2012), hlm. 160. pernyataan ada tiga gelas berwarna merah, hitam dan putih. Kemudian ditanyakan, gelas berwarna apa yang akan terlihat lebih terang dan jelas. Pada kondisi ini, anak akan mengalami kesulitan dalam menjawab, kemampuan kognitif anak memiliki keterbatasan untuk bernalar, sehingga kemungkinan jawaban anak akan bervariasi karena tidak berdasarkan penalaran ilmiah dan objektif. Pertanyaan tersebut akan terjawab dengan baik ketika ketiga gelas berwarna tersebut dihadirkan dihadapan si anak.

Pada fase ini, kemampuan kognitif anak mengalami perkembangan yang pesat. Dalam keadaan normal, kemampuan anak usia sekolah dasar berkembang secara bertahap. Pada masa sebelumnya kemampuan berfikir anak masih bersifat imajinatif, subjektif dan egosentris, sedangkan ketika anak memasuki masa sekolah, daya pikir anak akan berkembang secara perlahan kearah berfikir konkret dan egosentris juga berkurang. Ketika memandang sesuatu dihadapannya, anak mulai memfungsikan akal untuk berfikir secara rasional dan objektif serta sudah dapat memecahkan suatu masalah secara logis.

Pada tahap operasional konkret, anak memiliki pemahaman yang lebih baik dari pada anak praoperasional (2-7 tahun) mengenai konsep spasial, sebab-akibat, pengelompokan, penalaran induktif dan deduktif, konservasi serta konsep angka/matamatik. ${ }^{11}$ Adapun pengertian mengenai konsep-konsep tersebut yaitu, pertama, konsep sebab-akibat adalah suatu kemampuan kognitif seorang anak dalam mengetahui proses terjadinya suatu perubahan dari suatu objek yang ia lihat. Misalnya, anak bisa mengetahui bahwa ketika suatu wadah (botol) semakin diisi air maka akan semakin berat, anak dapat menarik kesimpulan bahwa penyebab bertambahnya berat karena air dan pada waktu itu juga anak akan berfikir bahwa setiap air memiliki berat.

${ }^{11}$ Papalia, Old \& Feldman, Human Development terj. Briyan Marswendy, (Jakarta: Salemba Humanika, 2009), hlm. 443. 
Kedua, konsep pengelompokan yaitu kemampuan kognitif seorang anak dalam menggolongkan suatu objek yang memiliki kesamaan atau perbedaan jenis, warna dan ukuran. Kemampuan kognitif anak usia dasar pada tahap operasional konkret mengenai pengelompokan meliputi berbagai kemampuan yang relative canggih, seperti serasi (seriation), penyimpulan transitif, dan inklusi kelas, yang secara bertahap meningkat antara masa kanak-kanak awal dan menengah. ${ }^{12}$ Serasi (seration) adalah kemampuan untuk menyusun stimulus atau suatu objek berdasarkan dimensi kuantitatif, seperti panjang, warna, berat dan lain sebagainya. ${ }^{13}$ Sebagai contoh, anak diberi 10 jenis pensil yang berukuran panjang yang berbeda dan diletakan secara acak di atas meja, anak-anak sudah bisa mengurutkan pensil tersebut dari ukuran terpendek hingga yang paling panjang.

Penyimpulan transitif(transitive inference) adalah kemampuan untuk menggabungkan secara logis hubungan untuk memahami kesimpulan tertentu. ${ }^{14}$ Misalnya, seorang anak ditunjukan tiga buah bola yang berwarna merah, kuning dan hijau. Merah berukuran lebih besar, kuning berukuran sedikit lebih kecil dari merah dan hijau berukuran lebih kecil dari kuning. Tanpa melakukan perbandingan, ia akan dapat menyimpulkan bahwa bola warna merah memiliki ukuran yang paling besar. Selanjutnya inklusi kelas (class inclusion) adalah kemampuan melihat hubungan antara keseluruhan dan bagian-bagiannya. ${ }^{15}$ Misalnya, ketika anak diberi seikat bunga yang berisi 5 tangkai melati-3 tangkai mawar berwarna putih dan disetiap tangkai memiliki banyak kelopak bunga. Ketika anak ditanya, apakah lebih banyak bunga melati atau lebih banyak jumlah kelopak bunga, maka anak akan

${ }^{12}$ Ibid., hlm. 444.

${ }^{13}$ John W. Santrock, Perkembangan Anak, (Jakarta : Penerbit Salemba Humanika, 2011), hlm. 188.

${ }^{14}$ Ibid., hlm. 188.

${ }^{15}$ Papalia, Old \& Feldman, Human Development, terj. Briyan Marswendy, hlm. 144. menjawab jumlah kelopak bunga yang lebih banyak, karena setiap bunga terdapat banyak kelopak bunga. Berbeda dengan anak pada tahap praoperasioal, mereka akan cenderung menjawab jumlah bunga melati lebih banyak, karena anak hanya melihat perbandingan bunga melati dengan bunga mawar putih.

Ketiga, penalaran induktif dan deduktif. Penalaran induktif yaitu suatu cara berfikir dengan melihat fakta secara umum kemudian menarik kesimpulan secara khusus, sedangkan penalaran deduktif sebaliknya. Menurut Piaget, anak-anak pada tahap operasional konkret hanya menggunakan penalaran induktif, mulai dari pengamatan mengenai anggota partikular dari kelas orang-orang, hewan, objek, atau kejadian, kemudian mereka mengambil kesimpulan umum mengenai kelas sebagai keseluruhan. ${ }^{16}$ Anak yang berfikir operasional konkret, ketika harus menyelesaikan suau masalah, maka ia langsung memasuki masalahnya. Berbeda dengan anak yang berfikir formal (11 tahun ke atas), mereka akan terlebih dahulu berfikir secara teoritis, kemudian mengidentifikasi atau mengkalisifikasi, baru kemudian mencari solusi dan bergerak menyelesaikan masalahnya. ${ }^{17}$ Sebagai contoh, jambu berwarna merah memiliki rasa yang manis, anak akan berkesimpulan bahwa setiap jambu berwarna merah rasanya manis, padahal belum tentu demikian.

Keempat, konsep konservasi yakni pemahaman bahwa karakteristik fisik suatu benda mati akan tetap meskipun wujudnya berubah. ${ }^{18}$ Anak yang berada pada tahap operasional konkret telah mampu menyadari konservasi, sebagaimana dalam sebuah eksperimen, seorang anak dihadapkan dengan dua gumpalan tanah liat dengan ukuran tanah yang sama tetapi dibuat kedalam bentuk yang

${ }^{16}$ Ibid., hlm. 445.

${ }^{17}$ F. J. Monks, A. M. P. Knoers \& Siti Rahayu Adinuto, Psikologi Perkembangan. (Yogyakarta : Gajah Mada University Press, 2014), hlm. 223.

${ }^{18}$ Carole Wade, Carol Tavris \& Maryanne Garry, Psikologi, terj. Padang Mursalin, Dinastuti \& Novi Vidya Santika, (Jakarta : Penerbit Erlangga, 2016), hlm. 167. 
berbeda, yang satu berbentuk panjang dan yang satu lagi berbentuk bulat. Kemudian, anak diberi pertanyaan apakah gumpalan tanah yang berbentuk panjang lebih banyak dibandingkan dengan yang berbentuk bulat. Anak pada usia 7 atau 8 tahun, sebagian besar menjawab bahwa ukuran tanah tetap sama. ${ }^{19}$ Pemahaman tentang konsep konservasi memberikan pemahaman bahwa suatu ukuran benda (panjang, berat, volume dan massa) tidak akan berubah kendati bentuknya mengalami perubahan.

Kelima, konsep angka/matematik yaitu kemampuan anak dalam mengolah angka, seperti penjumlahan, pengurangan, perkalian, dan pembagian. Pada usia 6 atau 7 tahun, banyak anak dapat menghitung di dalam kepala. ${ }^{20}$ Kemampuan mengelola angka ini menjadi pembeda dengan kemampuan dalam disiplin ilmu lain yang secara umum mesti dihadirkan objeknya. Setiap level usia atau tingkatan kelas, anak-anak memiliki kemampuan matematik yang berbeda, semakin tinggi tingkatan kelas, maka akan semakin baik kemampuan matematikanya.

Berdasarkan penjelasan diatas, bukan berarti bahwa setiap tahapan usia 7-11 tahun, anak-anak memiliki kemampuan yang sama. Penjelasan menurut Piaget tersebut hanya menggambarkan secara umum bahwa pada saat anak- anak menginjak usia operasional konkret, anak-anak memiliki kemampuan sebagaimana yang dijelaskan. Setiap tingkatan usia, anak-anak tentu memiliki kemampuan yang berbeda-beda baik kemampuan dalam bernalar, berfikir logis, mengingat, menghafal, memahami dan menganalisis. Anak-anak memiliki kemampuan berfikir tentang suatu hal dengan tingkat kesukaran yang berbeda dan perbedaan-perbedaan itu yang menjadi dasar dalam menentukan tingkat kesukaran materi ajar, Strategi, model dan metode pembelajaran di SD/MI.

${ }^{19}$ John W. Santrock, Perkembangan Anak, terj. Mila Rachmawati dan Anna Kuswanti..., hlm. 256.

${ }^{20}$ Papalia, Old \& Feldman, Human Development, terj. Briyan Marswendyhlm..., hlm. 447.
Kemampuan kognitif anak akan semakin meningkat disetiap waktunya. Misalnya, semakin tinggi kelas maka materi yang dipelajari akan semakin sukar atau kompleks. Peningkatan daya kognitif dapat terjadi karena dipengaruhi oleh banyak faktor, seperti volume otak, makananan, pendidikan, pengalaman dan lingkungan. Akan tetapi, dalam konteks perkembangan kognitif dari suatu proses, faktor yang sangat berpengaruh adalah faktor pengalaman dan lingkungan. Sebagaimana yang dikemukanan oleh Piaget bahwa manusia yang akif secara terus menerus mengadakan penyesuaian diri (adaptasi) dalam proses interaksinya terhadap lingkungan. ${ }^{21}$ Alasan logis selanjutnya yaitu ketika anak sudah melewati berbagai aktifitas atau proses pendidikan maka pengetahuan dan wawasan anak bertambah. Ketika anak mendapatkan hal yang lebih rumit, anak sudah memiliki kesiapan untuk berfikir tentang hal itu, baik untuk mempelajari maupun memecahkan suatu permasahan yang ada.

Berdasarkan hasil analisis penulis, berikut ini dideskripsikan terkait kemampuan kognitif anak menurut usia /kelas dan implikasinya dalam kegiatan belajar menagajar :

\section{Kemampuan kognitif anak usia tujuh tahun (kelas satu SD/MI)}

Kemampuan kognitif anak pada usia ini masih pada tahap pengetahuan dan pemahaman yang masih terbatas, meskipun anak sudah masuk ada fase operasional konkret. Dalam konteks pendidikan, mengacu pada teori Taksonomi Bloom bahwa pada fase ini anak memasuki jenjang yang paling rendah yaitu $\mathrm{C} 1$ (mengingat) dan awal jenjang C2 (memahami). Kata operasional (verb) pada fase ini seperti menyusun daftar, mengingat, menyebutkan, mengenali, menuliskan kembali, mengulang, menamai, mengelompokan dan membedakan hal bersifat sederhana. ${ }^{22}$ Faktanya, anak juga

${ }^{21}$ Sumanto, Psikologi Perkembangan : Fungsi dan Teori, (Yogyakarta : PT. Buku Seru, 2014), hlm. 154.

${ }^{22}$ Chairul Anwar, Teori-teori Pendidikan Klasik Hingga Kontemporer, (Yogyakarta : IRCiSoD, 2017), hlm. 207. 
sudah masuk pada ranah C3 (menerapkan) yang masih dalam level rendah. Sebagai contoh, ketika belajar membaca anak sudah bisa mengeja bacaan, menyalin tulisan dan berbicara bahasa Indonesia serta bertanya ketika sedang belajar. ${ }^{23}$ Anak sudah mampu menyebutkan kembali dari apa yang disebutkan oleh guru, baik berupa huruf, kata dan kalimat sederhana.

Kosa kata yang mesti diberikan yaitu kosa kata yang sering digunakan dalam aktifitas sehari-hari (daily activity) dan berkemungkinan sering didengar oleh anak. Anak belum bisa diberikan kosa kata ilmiah yang tinggi atau yang jarang digunakan dalam aktifitas sehari-hari. Pada pembelajaran bahasa Indonesia, metode pembelajaran yang tepat digunakan yaitu metode mengeja dan metode struktur analitis sintesis atau dikenal dengan istilah metode SAS. ${ }^{24} 24$ Metode mengeja yaitu pengenalan yang dimulai dari elemen terkecil (huruf), kata hingga kalimat yang bermakna. Metode SAS yaitu dengan cara membacakan suatu teks, kemudian mengurainya menjadi kalimat-kalimat, kata-kata hingga menjadi suku kata (huruf) dan dilatih untuk menuliskan huruf, kata dan kalimat sederhana. Ketika guru mengenalkan kosa kata, diupayakan untuk dilengkapi dengan objek bendanya (empirik) supaya anak tidak berkhayal.

Kemampuan matematika anak pada fase ini masih dalam batasan pengenalan angka, penjumlahan dan pengurangan. Kemampuan kognitif anak belum mampu mengoperasikan bilangan perkalian dan pembagian. Sesuai dengan fase operasional konkret, metode pembelajaran matematika pada fase ini sebaiknya menggunakan alat bantu seperti mesin hitung manual, jari tangan, gambar yang detil dan menggunakan bantuan benda seperti buah, batu, kertas dan sebagainya. Pada tahap ini, anak-anak juga sudah bisa dikenalkan

\footnotetext{
${ }^{23}$ Patimah, Efektifitas Metode Pembelajaran Dongeng Dalam Meningkatkan Kemampuan Literasi Anak Pada Jenjang Usia Sekolah Dasar, (Jurnal Pendidikan Guru MI, Vol. 2, No. 2, 2005), hlm. 7.

${ }^{24}$ Chairul Anwar, Teori-teori Pendidikan Klasik Hingga Kontemporer..., hlm. 136-137.
}

jenis-jenis warna dan simbol-simbol sederhana, seperti lambang-lambang, bentuk bangun datar dan benda-benda yang terdapat di lingkungan sekitar.

Selanjutnya, pada fase ini, pembelajaran sebaiknya menggunakan strategi pembelajaran kontekstual yaitu mengkaitkan materi dengan kondisi nyata dan berhubungan dengan kehidupan sehari-hari. Anak bisa diajak belajar di alam terbuka, supaya tidak jenuh dan bosan, karena anak usia 6-7 tahun cepat merasa lelah dalam berfikir, fakta ini juga yang menjadi dasar jumlah jam belajar di sekolah yang hanya berkisar 2-3 jam. Ketika belajar lebih dari 3 jam, anak tidak bisa fokus mengikuti KBM. Pada proses KBM, guru mesti mendidik dan mengajar secara intens, karena pada fase ini, anak-anak masih berada pada masa bermain yang membutuhkan kesenangan. Anakanak belum bisa belajar dengan nuansa yang formal, sehingga guru mesti kreatif mendesain pembelajaran yang menyenangkan, seperti dengan cara bernyanyi, menggunakan teks cerita, mendongeng dan bermain peran.

\section{Kemampuan kognitif anak usia delapan tahun (kelas dua SD/MI)}

Kemampuan kognitif pada fase ini lebih baik dari pada fase sebelumnya. Dalam konteks pendidikan, anak sudah memasuki jenjang C2 (memahami) dan masuk pada tahap C3 (menerapkan) yang semakin baik. Kata operasional (verb) pada fase ini seperti menerangkan, menjelaskan, menguraikan, membedakan, mengubah, mendeteksi, menduga, mengelompokkan, memberi contoh dan menghitung. ${ }^{25}$ Misalnya, anak- anak sudah bisa membaca teks cerita dengan lancar, membedakan jenis- jenis warna yang memiliki kemiripan dan dapat mengerjakan tugas lembar kerja berbentuk tabel, seperti mengisi kolom, menjodohkan dan melengkapi. Anak sudah dapat memahami isi suatu teks (cerpen dan dongeng) dan menjawab soal-soal yang berkaitan dengan teks.

\footnotetext{
${ }^{25}$ Ibid., hlm. 193-195.
} 
Pada fase ini, anak juga sudah bisa mengelompokan dan mengurutkan suatu objek benda menurut jenis, ukuran dan warna secara cepat dan tepat. Selaras dengan hasil penelitian Piaget (1952) bahwa pada usia 7-8 tahun, seorang anak dapat mengetahui hubungan yang terdapat dalam sekumpulan tingkat (objek) dan menyusunnya berdasarkan ukuran. ${ }^{26}$ Sebagai contoh, ketika diberi 10 tongkat dengan ukuran panjang yang berbeda, anak sudah bisa mengurutkan tongkat dimulai dari yang paling pendek sampai yang paling panjang. Pada $\mathrm{KBM}$, konsep ini bisa diterapkan dalam muatan materi ajar, seperti mempelajari jenis hewan, buah-buahan dan objek lainnya.

Kemampuan matematika pada usia ini sudah semakin baik, anak sudah dapat memahami jenis ukuran (berat, panjang, dan volume), tetapi belum sampai pada tahap perubahan ukuran dan sudah bisa mengenal diagram batang. Anak sudah bisa mengoperasikan perkalian dan pembagian, tetapi masih sebatas bilangan asli. Namun, ketika diberi soal yang berbentuk angka yang berbeda, biasanya anak akan mengalami kesulitan dalam menjawabnya. Misalnya, anakanak diajarkan perkalian angka dibawah 10, ketika diberi pertanyaan dengan angka diatas 10 (dua dijit angka), tidak jarang anak mengalami kesulitan untuk menjawabnya. ${ }^{27}$ Anak belum bisa mengoperasikan perkalian dan pembagian angka desimal dan pada skala angka yang mencapai ribuan.

Pembelajaran yang berbasis alam (lingkungan sekitar) sangat relevan dengan fase ini, karena anak membutuhkan lingkungan belajar di alam yang terbuka, supaya tidak jenuh dan bosan. Selain dari pada itu, agar anak dapat memahami materi dengan lebih mudah, sebaiknya guru menghadirkan contoh nyata dan melakukan percobaan (eksperimen) terhadap materi yang dipelajari. Pada usia 7-8

${ }^{26}$ Papalia, Old \& Feldman, Human Dovelopment (Psikologi Perkembagan) : Bagian I s/d IV, terj. Anwar K.A., (Jakarta : Kencana Prenada Media Group, 2008), hlm. 437.

${ }^{27}$ Hasil Wawancara dengan Guru di SDN MI AlFazar Pringsewu Lampung, 16 Januari 2018. tahun, anak bisa fokus mengikuti pembelajaran dengan durasi yang hanya berkisar 2-3 jam, selebihnya anak akan merasa lelah, mengantuk dan cenderung mencari aktifitas bermain. Anak sudah bisa belajar dengan nuansa yang formal, tetapi masih membutuhkan pembelajaran yang menyenangkan, seperti pembelajaran yang berbasis permainan (game).

\section{Kemampuan kognitif anak usia sembilan tahun (kelas tiga SD/MI)}

Pada fase ini, kemampuan kognitif semakin meningkat. Anak sudah bisa memecahkan masalah yang lebih rumit, karena anak sudah cukup banyak memiliki pengetahuan, wawasan dan pengalaman dari proses-proses sebelumnya. Pada fase ini, anak masuk pada ranah kognitif yang lebih tinggi yaitu ranah menerapkan (C3). Kemampuan menerapkan adalah kemampuan menggunakan atau mengaplikasikan materi yang sudah dipelajari pada situasi yang baru dan menyangkut penggunaan aturan dan prinsip. ${ }^{28}$ Kata operasional (verb) pada fase ini yaitu memilih, mengubah, menghitung, mendemontrasikan, memodifikasi, meramalkan, menghasilkan, menghubungkan, menunjukan dan mempraktikan. ${ }^{29}$

Jika pada tahap sebelumnya, materi yang diberikan cenderung berkaitan dengan objek yang sering ditemukan dalam kehidupan seharihari, pada tahap ini anak sudah bisa berfikir lebih dalam dan dapat berimajinasi terhadap suatu objek yang digambarkan. Misalnya, anak sudah bisa dikenalkan dengan sistem tata surya, seperti planet, komet dan bintang beserta sifatsifatnya dalam bentuk visual atau audio visual. Anak- anak sudah bisa memahami sebab-akibat terjadinya sesuatu dan dapat mencari solusi dalam memecahkan suatu masalah, tetapi masih membutuhkan bantuan guru atau teman sebaya.

Kemampuan matematika anak semakin baik, anak tidak hanya mengenal jenis bangun datar, tetapi sudah bisa menghitung luas bangun

${ }^{28}$ Chairul Anwar, Teori-teori Pendidikan Klasik Hingga Kontemporer..., hlm. 194.

${ }^{29}$ Suharsimi Arikunto, Dasar-dasar Evaluasi Pendidikan, (Jakarta : PT Bumi Aksara, 2013), hlm. 151. 
datar dan sudah bisa mengenal bangun ruang. Anak juga dapat memahami proses perubahan bentuk bangun, misalnya bangun persegi dapat dibentuk menjadi dua bangun segitiga atau berbentuk jajar genjang. Anak dapat menghitung angka dalam pikiran tanpa menghitung dengan cara manual atau menulis. Misalnya, ketika ditanya tentang perkalian angka puluhan dengan satuan, anak bisa menjawab secara spontan, tetapi ketika mengalikan angka puluhan dengan puluhan bahkan ratusan, anak belum bisa menjawabnya tanpa dengan bantuan perhitungan manual.

Pada fase ini, sudah bisa diterapkan sistem pembelajaran dengan diskusi kelompok. Akan tetapi, membutuhkan perhatian guru dan kontrol yang lebih intensif dalam pelaksanaanya, sebab kemampuan anak untuk berdiskusi masih terbatas, kemampuan beride dan keterampilan bekerja samanya masih perlu dikembangkan. Selain dari itu, perhatian anak juga mudah goyah, sehingga membutuhkan pengendalian, pengawasan, dan bimbingan belajar yang lebih intensif. ${ }^{30}$ Pada usia 8-9 tahun, anak bisa fokus mengikuti pembelajaran dengan durasi dari 3-4 jam dalam satu hari.

\section{Kemampuan kognitifanak usia sepuluh tahun (kelas empat SD/MI)}

Pada fase ini anak memiliki daya kritis yang semakin baik, anak dapat menelaah suatu masalah secara mendalam dengan berbagai dimensi. Kemampuan kogntif pada ranah C3 (menerapkan) jauh lebih baik dibandingkan pada usia sebelumnya, anak tidak hanya dapat menghitung dan mengubah melainkan sudah dapat membandingkan objek-objek yang ada. Pada usia 9-10 tahun, anak sudah memasuki jenjang C4 (menganalisis) yaitu "kemampuan untuk merinci atau menguraikan suatu bahan atau keadaan menurut bagian-bagian yang lebih kecil dan mampu memahami hubungan di antara bagian-bagian atau faktor-faktor

${ }^{30}$ Erliani Syaoidih, Pengembangan Model Pembelajaran Kooperatif Untuk Meningkatkan Keterampilan Sosial, (Jurnal Educar, Vol. 5, No. 1, 2007). satu dengan faktor-faktor lainnya. ${ }^{31}$ Anak sudah dapat menganalisis, mengkontraskan dan menghubungkan teori dengan fakta untuk menarik kesimpulan. Anak sudah berani menyalahkan sesuatu dengan alasan- alasan yang ilmiah.

Sebagaimana penagalaman penulis dalam mengajar, pada fase ini, anak memiliki kemampuan dalam menganalisis teks untuk memperoleh suatu pengetahuan dan pemahaman baru. Anak dapat menarik kesimpulan nilainilai positif dan negatif yang terkandung di dalamnya. Anak sudah bisa diberikan materi tentang sejarah (agama, kerajaan, zaman penjajahan dan lainnya). Pada dasarnya, usia 10 tahun anak sudah memasuki ranah sintesis (C5) tetapi masih pada level yang sangat sederhana, seperti dapat mengategorikan dan mengombinasikan banyak objek secara logis. Pada pembelajaran IPA, anak sudah bisa mempelajari objek yang tidak berwujud, seperti tentang udara dan gas serta dapat memahami tentang perubahan wujud benda. Kemampuan matematika anak juga semakin baik, anak dapat menyelesaikan soal-soal yang lebih rumit, misalnya mengoperasikan bilangan pecahan dan desimal, menghitung luas sebagian dari suatu bangun datar, menghitung volume bangun ruang dan menghitung perubahan ukuran benda, seperti kilo gram ke gram, centi meter ke meter dan lain sebagainya. Anak juga dapat mengoperasikan perkalian dan pembagian dalam memecahkan soal yang berbentuk narasi atau cerita.

Pada fase ini, dalam pembelajaran, anak sudah bisa diterapkan sistem belajar kooperatif yaitu sistem pembelajaran dengan cara anak belajar dan bekerja sama (kaloboratif) dalam kelompok-kelompok kecil. ${ }^{32}$ Salah satu model pembelajaran kooperatif yang cocok pada fase ini yaitu Student-Teams-Achievment Divisions (STAD). Pembelajaran Kooperatif tipe STAD merupakan salah satu tipe pembelajaran

\footnotetext{
${ }^{31}$ Chairul Anwar, Teori-teori Pendidikan Klasik Hingga Kontemporer..., hlm. 194.

${ }^{32}$ Rusman, Model-model Pembelajaran, Cet. KeIV, (Jakarta : PT RajaGrafindo Persada, 2012), hlm. 202.
} 
kooperatif dengan menggunakan kelompokkelompok kecil dengan jumlah anggota 4-5 orang anak, setiap kelompok diberikan tugas untuk diskusikan dan kemudian dilanjut dengan kuis atau tanya jawab. ${ }^{33}$ Model pembelajaran tersebut dapat melatih anak dalam berkomunikasi (sharing), bertkukar ide dan gagasan dengan temannya dalam memecahkan suatu permasalahan. Anak-anak bisa diajak bernalar kritis terhadap objek-objek yang belum mereka ketahui sebelumnya.

\section{Perkembangan kognitif anak usia sebelas sampai dua belas tahun ke atas dan implikasinya dalam kegiatan belajar mengajar.}

Pada usia sebelumnya, anak bisa berfikir logis dan sistematis yang mangacu terhadap objek empirik (nyata) yang dapat di tangkap oleh indra. Berbeda dengan pada fase anak yang berada pada usia 11-12 tahun ke atas, anak sudah dapat memikirkan sesuatu yang akan atau mungkin terjadi (hipotesis) dan sesuatu bersifat abstrak. Fase ini disebut dengan fase operasional formal. ${ }^{34}$ Fase ini merupakan tahap akhir dalam perkembangan kognitif menurut Piaget. Menurut Ginsburg dan Opper (1988) pada tahap ini, anak dapat berfikir fleksibel dan efektif, serta mampu berhadapan dengan persoalan yang kompleks. ${ }^{35}$ Anak sudah dapat berfikir tentang objek yang bersifat abstrak, misalnya anak diberi pertanyaan seperti : Jika Joe lebih pendek dari pada bob, dan Joe lebih tinggi dari pada Alex, siapakah yang paling tinggi dari mereka? Maka anak akan dapat menjawabnya dengan baik tanpa harus menghadirkan orangorang tersebut dihadapannya. ${ }^{36}$ Berbeda dengan

\footnotetext{
${ }^{33}$ Moh. Rifa'i, Meningkatkan Prestasi Belajar Anak Dengan Pembelajaran STAD Pada Pembelajaran IPS Anak Kelas IV Min Manisrejo Kota Madiun, (Jurnal Premiere Educandum, Volume 4 Nomor 2, 2014), hlm. 156-169.

${ }^{34}$ Desmita, Psikologi Perkembangan..., hlm. 195.

${ }^{35}$ Paul Suparno, Teori Perkembangan Kognitif Jean Piaget, (Yogyakarta : Penerbit Kanisius, 2001), hlm. 88.

${ }^{36}$ Willam Crain, Teori Perkembangan : Konsep dan Aplikasi, terj. Yudi Santoso, Cet. Ke- 2, (Yogyakarta : Pustaka Belajar, 2014), hlm. 200.
}

fase operasional konkrit yang mesti dihadirkan objek nyatanya.

Pada fase operasional formal, anak sudah menggunakan pemikiran hopotesis-deduktif yakni mengembangkan hipotesa-hipotesa atau prediksi- prediksi terbaik, berfikir sistematis dalam menyusun langkah-langkah strategis dalam menyelesaikan suatu permasalahan. ${ }^{37}$

Proses berfikir seperti ini menuntut pola-pola berfikir tingkat tinggi, seperti memahami setiap variabel dan hubungan antar variabel. Model siklus belajar hipotesisdeduktif paling baik digunakan dalam rangka mengembangkan daya kritis anak yang pada gilirannya berpengaruh terhadap peningkatan pemahaman konsep. ${ }^{38}$ Pada fase ini, dalam konteks pendidikan, anak memasuki level kelas lima dan enam. Pada usia 11 tahun (kelas lima $\mathrm{SD} / \mathrm{MI}$ ), kemampuan kognitif anak memasuki ranah C5 (mengevaluasi/menilai) dan C6 (menciptakan) sedangkan pada usia 12 tahun ke atas (kelas enam SD/MI) masuk pada ranah kognitif C5 (mengevaluasi/menilai) dan C6 (mencipta) yang lebih baik.

Anak mampu berfikir secara kritis, ketika dihadapkan dengan masalah, anak akan memahami sebab-akibat terlebih dahulu, baru kemudian menyusun langkah untuk menyelesaikannya. Anak melihat suatu objek tidak hanya satu dimensi tetapi dengan berbagai dimensi. Misalnya, ketika belajar tentang listrik anak tidak hanya mengetahui bahwa listrik bisa menghidupkan bola lampu saja, melainkan anak mampu berfkir terkait sumber listrik, proses terjadinya perubahan energi listrik, manfaat energi listrik dan bahkan dapat membuat suatu rangkaian listrik.

Daya ingat anak semakin kuat dan sudah bisa berpikir strategis serta menyusun siasat. Sebagai contoh dalam suatu penelitian menemukan bahwa dua orang anak berusia 10

\footnotetext{
${ }^{37}$ John W. Santrock, Perkembangan Anak, terj. Mila Rachmawati dan Anna Kuswanti..., hlm. 258.

${ }^{38}$ Adnyana, P., G., Keterampilan Berfikir Kritis dan Pemahaman Konsep Anak Pada Model Siklus Belajar Hipotesa Deduktif, (Jurnal pendidikan dan Pengajaran, Jilid 45, No. 3, 2012)
} 
dan 11 tahun yang berpengalaman bermain catur (ahli) mampu mengingat lebih banyak informasi mengenai bidak catur dibandingkan dengan mahasiswa yang bukan pemain catur (pemula). ${ }^{39}$ Hasil penelitian tersebut menunjukan bahwa kompetensi kogitif anak pada usia ini sudah bisa berfikir strategis sistematis. Kemampuan matematika anak semakin kompleks, jika sebelumnya hanya dapat menghitung luas bangun datar, pada fase ini anak sudah bisa menghitung luas, keliling dan volume bangun ruang.

Anak bisa mengerjakan soal-soal yang rumit, seperti operasi akar dan mengoperasikan angka yang bernominal tinggi (ribuan dan jutaan).

Pada fase ini sudah bisa diterapkan model pembelajaran yang terpusat pada siswa (student center), salah satunya yaitu model pembelajaran Inkuiri. Model pembelajaran Inkuiri adalah suatu pola pembelajaran dari proses pengamatan menjadi pemahaman. Sebagaimana dalam suatu penelitian membuktikan bahwa sikap ilmiah anak kelas lima dalam pembelajaran IPA berhubungan secara signifikan terhadap model pembelajaran inkuiri, artinya bahwa sikap ilmiah anak semakin baik ketika diterapkan model pembelajaran inkuiri. ${ }^{40}$ Hasil penelitian tersebut menjadi bukti juga bahwa anak usia 11 tahun (kelas lima SD/MI) sudah bisa diterapkan model pembelajaran yang pada prinsipnya membutuhkan kemampuan berfikir dan daya kritis tingkat tinggi.

Level kemampuan berfikir anak pada usia ini juga tidak hanya bisa belajar dengan metode kooperatif maupun inkuiri, tetapi sudah bisa diterapkan dengan model pembelajaran kontruktivisme. Konstruktivisme dalam

39 39 John W. Santrock, Perkembangan Anak, terj. Mila Rachmawati dan Anna Kuswanti..., hlm. 193.

${ }^{40}$ N.L. Santiasih, A.A.I.N. Marhaeni, \& I.N. Tika, Pengaruh Model Pembelajaran Inkuiri Terbimbingan Terhadap Sikap Ilmiah Anak dan Hasil belajar IPAAnak Kelas V SD N0. 1 Kerobokan Kecamatan Kuta Utara Kabupaten Bandung, (Journal Program Pasca Sarjana Universitas Ganesha Program Studi Pendidikan Dasar, Vol. 3, 2013). pembelajaran adalah suatu filosofi yang didasari dari suatu paradigma dimana proses pembentukan pengetahuan pada individu manusia tidak serta merta hasil dari transfer ilmu saja, melainkan hasil dari kegiatan mental yang ditunjang oleh proses pengalaman untuk membangun pemahaman secara individu. ${ }^{41}$ Suatu penelitan membuktikan bahwa model pembelajaran kontruktivisme dapat meningkatkan hasil belajar dan keaktifan siswa kelas enam di SD 6 BPK Penabur Bandung. ${ }^{42}$

Metode kontruktivisme sangat relevan dengan pemikiran Piaget, bahwa pengetahuan itu dibentuk murid dalam berhadapan dengan lingkungan atau objek yang dipelajarinya, dalam pendidikan dikenal dengan istilah belajar operatif yaitu proses pembelajaran yang menuntut siswa aktif dalam memahami konsep-konsepnya. ${ }^{43}$ Menurut penulis, model pembelajaran kontruktivisme tidak bisa diterapkan terhadap seluruh tingkatan usia atau terhadap anak yang berada pada ranah kognitif yang masih rendah seperti anak yang berusia 7-9 tahun, karena pembelajaran dengan model tersebut menuntut anak bernalar tinggi untuk memaknai sesuatu yang belum pernah diketahui sebelumnya dan tehadap hal yang bersifat abstrak.

Pada fase ini juga, anak sudah memiliki kemampuan untuk membuat pertimbanganpertimbangan terhadap suatu kondisi dan menentukan pilihan yang terbaik dengan dasar ilmiah. Anak sudah dapat membuat suatu inovasi atau menciptakan sesuatu yang baru berdasarkan pengetahuan-pengetahuan sebelumnya. Anak dapat membuat teks puisi, pidato, membuat karangan cerita, dan menciptakan suatu karya seni. Pada konteks kemampuan matematika,

${ }^{41}$ Lily Barlia, Konstruktivisme dalam Pembelajaran Sains Di SD : Tinjauan Epistemologi, Ontologi dan Keraguan dalam Praksisnya, (Jurnal Cakrawala Pendidikan, Th. XXX, No. 3, 2011).

${ }^{42}$ Hapsari, Penerapan Model Pembelajaran Kontruktivisme Untuk Meningkatkan Hasil Belajar IPA..., hlm. 45.

${ }^{43}$ Paul Suparno, Teori Perkembangan Kognitif Jean Piaget..., hlm. 122-123. 
anak sudah bisa membuat peta pemikiran dan mencari cara-cara tersendiri dalam mengerjakan soal.

\section{KESIMPULAN}

Perkembangan kognitif anak usia dasar merupakan salah satu aspek penting yang mesti dipahami dalam proses pendidikan khususnya kegiatan belajar mengajar (KBM). Kemampuan kognitif anak usia dasar berbeda-beda disetiap tingkatan usianya. Sebagaimana menurut teori kognitif Piaget, pada anak usia dasar, perkembangan kognitif anak terbagi menjadi dua fase yaitu pertama fase operasional konkret (usia 7-11 tahun) adalah fase dimana anak sudah bisa berfikir logis, rasional, ilmiah dan objektif terhadap sesuatu yang bersifat konkret atau nyata. Pada fase ini, dalam KBM, guru mesti memberikan materi pembelajaran yang bersifat empirik (nyata) bukan yang bersifat abstrak atau khayal. Proses KBM yang dilakukan mesti dikontekstualisasikan dalam kehidupan nyata, misalnya dengan menghadirkan contoh langsung dari materi yang dipelajari (modeling) dan melakukan praktek langsung (eksperimen).

Kedua fase operasional formal (11-12 tahun keatas) yaitu fase dimana anak sudah dapat memikirkan sesuatu yang akan atau mungkin terjadi (hipotesis) dan sesuatu bersifat abstrak. Pada fase ini, anak dapat berfikir kritis dan berfikir tingkat tinggi. Anak sudah dapat menggunakan pemikiran hopotesis-deduktif dan berfikir sistematis dalam menyusun langkah-langkah strategis untuk menyelesaikan suatu permasalahan. Dalam proses KBM, anak sudah bisa diterapkan model pembelajaran kontruktivisme dan inkuiri yang pada prinsipnya membutuhkan penalaran tinggi dan menuntut siswa untuk aktif berfikir, beride dan menarik makna dari hal yang empirik maupun abstrak.

Pentingnya pemahaman terhadap setiap tingkatan kemampuan kognitif anak tersebut menjadi pedoman prioritas dalam proses penyelenggaraan pendidikan. Mengingat, KBM akan efektif dan anak akan mendapatkan pengetahuan secara maksimal apabila materi, strategi, model dan metode pembelajaran yang digunakan sesuai dengan kemampuan kognitif anak, mulai dari tahap pemikiran yang konkret hingga pada tahap pemikiran yang formal.

\section{DAFTAR PUSTAKA}

Adinuto, R., S., Knoers, A.M.P. \& Monks, F.J., Psiklogi Perkembangan, (Yogyakarta : Gajah Mada University Press, 2014)

Adnyana, P., G., Keterampilan Berfikir Kritis dan Pemahaman Konsep Anak Pada Model Siklus Belajar Hipotesa Deduktif, (Jurnal pendidikan dan Pengajaran, Jilid 45, No 3, 2012)

Anwar, C. (2017). Teori-teori P e n d i d i k a n Klasik Hingga Kontemporer. Yogyakarta: IRCiSoD.

Arikunto, S., Dasar-dasar Evaluasi Pendidikan, (Jakarta : PT Bumi Aksara, 2013)

Barlia, L., Konstruktivisme dalam Pembelajaran Sains Di SD : Tinjauan Epistemologi, Ontologi dan Keraguan dalam Praksisnya, (Jurnal Cakrawala Pendidikan, Th. XXX, No. 3, 2011)

Calting, J., \& Ling, J, Psikologi Kognitif. (Noermalasari Fajar Widuri, Penerjemah), (Jakarta : Penerbit Erlangga, 2012)

Chamidah, N., A., Deteksi Gangguan Pertumbuhan dan Perkembangan Anak, (Jurnal Pendidikan Khusus, Vol. 5 No. 2, 2009)

Crain W., Teori Perkembangan : Konsep dan Aplikasi, terj. Yudi Santoso (Cet. Ke-2), (Yogyakarta : Pustaka Belajar, 2014)

Desmita, Psikologi Perkembangan, Cet. Ke-9, (Bandung : PT Remaja Rosdakarya, 2015) Ekayanti, D., et al., Analsis Materi Pokok SD/ MI, (Makasar : Pena Indis, 2017)

Feldman, D., R., Old, S.,W., S. \& Papalia, E., D., Human Dovelopment (Psikologi Perkembagan) : Bagian I s/d IV (A. K. Anwar, Penerjemah), (Jakarta : Kencana Prenada Media Group, 2008)

Feldman, Old \& Papalia, Human Development (Briyan Marswendy, Penerjemah, (Jakarta: Salemba Humanika, 2009)

Fudyantara, K., Psikilogi Perkembangan, (Yogyakarta : Pustaka Pelajar, 2001) 
Gamayanti, L., I., Sudargo, T. \& Puspitasari, D., F., Hubungan Antara Status Gizi dan Faktor Sosio Demografi dengan Kemampuan Kognitif Anak Sekolah Dasar Di Daerah Endemis Gaki, (Jurnal Gizi Indon, 34 (1) : 52-60, 2011)

Garry, M., Tavris, C. \& Wade, C., Psikologi (Padang Mursalin, Dinastuti \& Novi Vidya Santika, Penerjemah), (Jakarta : Penerbit Erlangga, 2016)

Wawancara dengan Guru di SDN MI Al-Fazar Pringsewu Lampung, 16 Januari 2018

Halimatussa'diah et al., Analisis Materi Pokok di SD/MI, (Makasar : Penerbit Pena Indis, 2017)

Hapsari, Rr., S., T., Penerpapan Model Pembelajaran Kontruktivisme Untuk Meningkatkan Hasil Belajar IPA, (Jurnal Pendidikan Penabur No. 16, Tahun Ke-10: 34-45, 2011)

Herdiansyah, H., Metodologi Penelitian Kualitatif untuk Ilmu Psikologi, (Jakarta: Salemba Humanika, 2015)

Julia Maria Van Tiel \& Widyorini, E., Tiel, V., M., J., Deteksi dan Penanganan Anak Cerdas Istimewa (Anak Gifted), Cet. Ke-2, (Jakarta : Prenadamedia Group, 2015)

Olson, H., M. \& Hergenhann, B., R., Theories Of Learning (Triwabowo, B.S, Penerjemah), (Jakarta : Prenada Media Group, 2012)

Palupi, P., A. \& Gunawan, I., Taksonomi BloomRevisi Ranah Kognitif: Kerangka Landasan Untuk Pembelajaran pengajaran, dan penilaian, (Journal Premiere Educandum : Pendidikan Dasar dan Pembelajaran, Vol. 2, No. 2, 2012)

Patimah, Efektifitas Metode Pembelajaran Dongeng Dalam Meningkatkan Kemampuan Literasi Anak Pada Jenjang Usia Sekolah Dasar, (Jurnal Pendidikan Guru MI, Vol. 2, No. 2, 2005)

Prawaira, A., P., Psikologi Pendidikan dalam Perspektif Baru, (Yogyakarta : Ar- Ruzz Media, 2016)
Rakhmawati, I., Peran Keluarga dalam Pengasuhan Anak, (Jurnal Bimbingan dan Konseling Islam, Vol. 6, No. 1, 2015)

Rifa'i, M., Meningkatkan Prestasi Belajar Anak Dengan Pembelajaran STAD Pada Pembelajaran IPS Anak Kelas IV Min Manisrejo Kota Madiun, (Jurnal Premiere Educandum, Volume 4 Nomor 2, 2014)

Rusman, Model-model Pembelajaran, Cet. Ke-IV, (Jakarta : PT RajaGrafindo Persada, 2012)

Santrock, W., J., Perkembangan Anak (Mila Rachmawati dan Anna Kuswanti, Penerjemah), (Jakarta : Penerbit Erlangga, 2007)

Santrock, W., J., Perkembangan Anak, (Jakarta: Penerbit Salemba Humanika, 2011)

Subagyo, J., Metode Penelitian dan Praktek, (Jakarta : Rhineka Cipta, 1991) Sugiyono, Memahami Penelitian Kualitatif, Cet. Ke12, (Bandung: Alfabeta, 2016)

Sumanto, Psikologi Perkembangan : Fungsi dan Teori, (Yogyakarta : PT. Buku Seru, 2014)

Suparno, P., Teori Perkembangan Kognitif Jean Piaget, (Yogyakarta : Penerbit Kanisius, 2001)

Syaoidih, E., Pengembangan Model Pembelajaran Kooperatif Untuk Meningkatkan Keterampilan Sosial, (Jurnal Educar, Vol. 5, No. 1, 2007)

Tika, N., I., Marhaeni, A.A.I.N., Santiasih, L.N., Pengaruh Model Pembelajaran Inkuiri Terbimbingan Terhadap Sikap Ilmiah Anak dan Hasil belajar IPA Anak Kelas V SD N0. 1 Kerobokan Kecamatan Kuta Utara Kabupaten Bandung, (Journal Program Pasca Sarjana Universitas Ganesha Program Studi Pendidikan Dasar, Vol. 3, 2013)

Upton, P., Psikologi Perkembangan (Noermalasari Fajar Widuri, penerjemah), (Jakarta : Penerbit Erlangga, 2012)

Widyorini E., \& Tiel, V., M., J., Deteksi dan Penanganan Anak Cerdas Istimewa (Anak Gifted), Cet. Ke-2, (Jakarta: Prenadamedia Group, 2015) 